\title{
Unknown Primary Tumor Pathologic Cervical Lymph Nodes TNM Finding v8
}

National Cancer Institute

\section{Source}

National Cancer Institute. Unknown Primary Tumor Pathologic Cervical Lymph Nodes

TNM Finding v8. NCI Thesaurus. Code C132665.

A pathologic finding about one or more characteristics of an unknown primary tumor, following the rules of the TNM AJCC v8 classification system as they pertain to staging of cervical lymph nodes. It applies to patients who are treated surgically with a cervical lymph node dissection. (from AJCC 8th Ed.) 